\title{
An Efficient Method of Vibration Diagnostics for Rotating Machinery using a Decision Tree*
}

\author{
BO SUK YANG ${ }^{\mathrm{a}, \dagger}$, CHUL HYUN PARK ${ }^{\mathrm{b}}$ and HO JONG KIM ${ }^{\mathrm{b}}$ \\ ${ }^{a}$ School of Mechanical \& Automotive Engineering, Pukyong National University, Pusan, Korea; \\ ${ }^{\mathrm{b}}$ Research \& Development Center, Korea Heavy Industries \& Construction Co., Changwon, Korea
}

(Received 15 May 1998; In final form 17 July 1998)

\begin{abstract}
This paper describes an efficient method to automatize vibration diagnosis for rotating machinery using a decision tree, which is applicable to vibration diagnosis expert system. Decision tree is a widely known formalism for expressing classification knowledge and has been used successfully in many diverse areas such as character recognition, medical diagnosis, and expert systems, etc. In order to build a decision tree for vibration diagnosis, we have to define classes and attributes. A set of cases based on past experiences is also needed. This training set is inducted using a result-cause matrix newly developed in the present work instead of using a conventionally implemented cause-result matrix. This method was applied to diagnostics for various cases taken from published work. It is found that the present method predicts causes of the abnormal vibration for test cases with high reliability.
\end{abstract}

Keywords: Vibration, Diagnostics, Expert system, Decision tree, Rotating machinery

\section{INTRODUCTION}

A number of rotating machines are installed in power plants and petroleum refinery plants. Malfunction of a rotating machine due to some defects may cause shutdown of the plants resulting in high maintenance cost. It has been considered very significant to detect the defects of the machines at an early stage. The defects can be detected early by using vibration signals, since vibration signals contain current dynamic characteristics of the rotating machines. Moreover, the abnormal vibra- tion is critical to operation of high speed rotating machines. So the necessity of vibration diagnostics for rotating machinery is gradually increasing. Vibration diagnosis require deep knowledge on dynamics of the rotating machines and operation principle, because vibration signals are very complicated and the causes of abnormal vibration are interrelated to one another. However, operators in the plants are usually not experts on the vibration of the rotating machines. Thus a lot of research has been done to make it possible for even an operator who is not an expert can diagnose the cause of

* This paper was originally presented at ISROMAC-7.

${ }^{\dagger}$ Corresponding author. Tel.: +82516206450. 
abnormal vibration using automatic diagnosis system. An expert system is a system that represents the knowledge of a special domain expert. Every expert system is composed of an inference engine and a knowledge base.

In this paper, the decision tree will be introduced to acquire the structured knowledge in the form of concepts and to build the knowledge base which is indispensable for the vibration expert system. The decision tree is a technology that builds the knowledge-based system by the inductive inference from cases and the decision tree itself can play the role of a diagnosis tool (Mui and $\mathrm{Fu}, 1980$ ). The induction task is to develop classification rules that can determine the class of any case from its values of the attributes. These classification rules will be expressed as a decision tree. Since the decision tree is induced from cases, a set of cases relevant to the special domain is needed for decision tree (Safavian and Landgrebe, 1991). This set is called the training set. Each case in the training set is described in terms of a collection of attributes and has known classes. Therefore, considering induction tree for vibration diagnosis, we first have to construct a training set relevant to the vibration diagnosis, and then induce the decision tree. The training set is generated using a result-cause matrix newly developed in the present work, instead of using a conventionally implemented cause-result matrix. Of algorithms for induction of decision tree, the algorithm developed by Quinlan $(1986 ; 1987 ; 1992)$ is basically adopted in this paper. The method developed is applied to a variety of cases taken from rotating machines to verify its reliability.

\section{DECISION TREE}

This technology for building knowledge-based systems by inductive inference from case histories is a typical algorithm used for construction of a model of the knowledge used by a human expert.

Because a decision tree executes supervised learning, classes and attributes must be established beforehand. The class is a category to which each case belongs. Each attribute measures some important features of a case, and may have either discrete or numeric value. All information about one case must be expressible in terms of a fixed collection of attributes. A set of training cases with known classes is called a training set. Training cases from which a classification rule is developed are known only through their values of a set of attributes, and the decision trees in turn are expressed in terms of these same attributes. In order to correctly classify each case in the training set, we start at the root of the tree, then evaluate the test, and take a branch appropriate to the outcome. The process continues until a leaf is encountered, at which time the case is asserted to belong to the class named by the leaf, i.e. the successive division of the set of training cases proceeds until all the subsets consist of cases belonging to a single class. Thus the classification rules are assigned to each node.

The above process is represented graphically in Fig. 1. Let $T$ be a training set. If $T$ is empty or contains only cases of one class, the simplest decision tree is just a leaf labeled with the class. Otherwise, if $X$ is any decision rule on a case with possible outcomes $O_{1}, O_{2}, \ldots, O_{n}$, each object in $T$ will give one of these outcomes for $X$. Thus, $X$ produces a partition $\left\{T_{1}, T_{2}, \ldots, T_{n}\right\}$ of $T$ with $T_{i}$ containing those cases having outcome $O_{i}$. If each subset $T_{i}$ could be replaced by a decision tree for $T_{i}$, the result would be a decision tree for all of $T$.

\subsection{Selection of Test}

The structure of the decision tree highly depends on selection of test $(X)$ as a root. As a criterion for

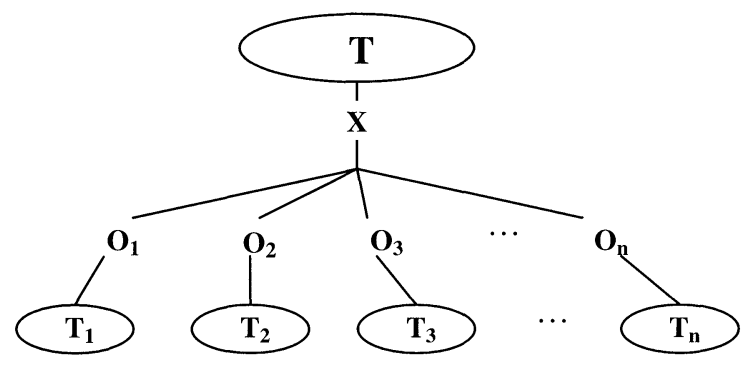

FIGURE 1 A decision tree structured with case in $T$. 
selection, we use the information-entropy evaluation function (IEEF) based on the information theory (Quinlan, 1986) proposed by Shannon. The calculation procedure of a IEEF is as follows:

Step 1: Calculate the average amount of information, info $(T)$, needed to identify the class of a case in a training set $T$.

$\operatorname{info}_{X}(T)=-\sum_{j=1}^{k}\left\{\frac{\operatorname{freq}\left(C_{j}, T\right)}{|T|} \times \log _{2}\left(\frac{\operatorname{freq}\left(C_{j}, T\right)}{|T|}\right)\right\}$

where $|T|$ is the number of cases in $T, C_{j}$ is the $j$-th class, $k$ is the number of classes, freq $\left(C_{j}, T\right)$ is the number of classes belonging to $C_{j}$ in $T$.

Step 2: Calculate the expected information, $\operatorname{info}(T)$, required for a test $X$ to classify $T$.

$$
\operatorname{info}_{X}(T)=-\sum_{i=1}^{n}\left\{\frac{\left|T_{i}\right|}{|T|} \times \operatorname{info}\left(T_{i}\right)\right\}
$$

where $n$ is the number of outcomes of $X, T_{i}$ is a subset of $T$ which is divided due to the $i$-th outcome.

Step 3: Calculate the mutual information, gain $(X)$, obtained from classification of $T$ depending on $X$.

$$
\operatorname{gain}(X)=\operatorname{info}(T)-\operatorname{info}_{X}(T) .
$$

Step 4: Calculate the split information, split $\operatorname{info}(X)$, obtained from classification of $T$ into $n$ subsets.

$$
\text { split } \operatorname{info}(X)=-\sum_{i=1}^{n}\left\{\frac{\left|T_{i}\right|}{|T|} \times \log _{2}\left(\frac{\left|T_{i}\right|}{|T|}\right)\right\}
$$

where $n$ is the number of outcomes of $X$.

Step 5: Calculate the ratio of the mutual information to the split information, $\mathrm{GR}(X)$.

$$
\operatorname{GR}(X)=\operatorname{gain}(X) / \operatorname{split} \operatorname{info}(X) .
$$

The gain ratio, $\mathrm{GR}(X)$, makes up for a shortcoming of the gain, gain $(X)$, which biases to an attribute of larger attribute value. The gain ratio also represents quantity of information provided by $X$ in a training set. Thus, we select an attribute or test of the highest GR value as the root of the decision tree.

\subsection{Evaluation of Unknown Attribute Values}

In the previous section, if an attribute value is unknown, the outcome of a test cannot be determined since every test is based on a single attribute. In real world, occasionally one may not obtain necessary data, which requires special treatment. Problems coming from the unknown attribute values can be classified into three categories, and are solved through the following processes.

\subsubsection{Generalization of the Gain Ratio}

Selection of a test on which the training set is partitioned is made on the basis of heuristic criteria such as the gain or the gain ratio. If the attribute values are unknown in the tests, one may not know relative desirability of the attributes due to shortage of information. Therefore, generalized gain ratios should be computed taking into account the shortage of information.

For an attribute, let $F$ be the ratio of a cause with known attribute values to total cases. The generalized gain $(X)$ is calculated by Eq. (6). The number of outcomes becomes $n+1$ considering that a case of an unknown attribute value be another set of attributes. Thus, the generalized gain ratio is obtained from Eq. (8).

$$
\operatorname{gain}(X)=F \times\left\{\operatorname{info}\left(T_{\text {known }}\right)-\operatorname{info}_{X}\left(T_{\text {known }}\right)\right\},
$$

$$
\begin{gathered}
\text { split } \operatorname{info}(X)=-\sum_{i=1}^{n+1}\left\{\frac{\left|T_{i}\right|}{|T|} \times \log _{2}\left(\frac{\left|T_{i}\right|}{|T|}\right)\right\}, \\
\operatorname{GR}(X)=\operatorname{gain}(X) / \operatorname{split} \operatorname{info}(X)
\end{gathered}
$$

where $T_{\text {known }}$ is a set of cases with known attribute values. 


\subsubsection{Partitioning of the Training Set}

Once a test has been selected, training cases with unknown values of the relevant attribute cannot be associated with a particular outcome of the test, and so cannot be assigned to a particular subset $T_{i}$.

We introduce a weighting factor, $w$, representing probability of a case to belong to a subset. If the case with seen outcome $O_{i}$ is assigned to a subset $T_{i}$, probability of belonging of the case to $T_{i}$ is 1 , while probability to remaining subsets is 0 . However, if the case is with an unseen outcome, the probability will be between 0 and 1 . In this case, the subset $T_{i}$ becomes a set of probabilistic cases.

\subsubsection{Classification of Unseen Cases}

When the decision tree is used to classify a case, the outcome will not be decided if the case has an unknown value for the attribute tested in the current decision node. Similarly as in the previous subsection, the system explores all possible outcomes and combines the resulting classifications arithmetically. That is, since there can be multiple paths from the root of a tree or subtree to leaves, a classification is a class distribution rather than a single class. A class with the highest probability becomes the class of the unseen case.

\subsection{Pruning}

Pruning is a simplification process of the decision tree. For a set with unseen cases, capacity of the classification is decreased and evaluation is not feasible. Pruning strengthens the classification for the population, and evaluates the decision tree to classify unseen cases, with reasonable degree of reliability. This evaluation presents reliability of the decision tree, and is called predictive accuracy. The inverse of the predictive accuracy is called predictive error rate. The following way (Quinlan, 1987) in which the recursive partitioning method can be modified to produce simpler trees is used in the present work.

Let $S$ and $L(S)$ be a subtree of a decision tree and the number of leaves belonging to $S$, respectively.
And let $\sum N$ and $\sum E$ be the sum of total leaves of $S$ and the sum of errors, respectively. In this case, the pruning assumes that, for unseen cases of $\sum N$, the number of misclassifications would be $\sum E+L(S)$ / 2 , following the continuity correction for a binomial distribution. The standard error, for the errors $\operatorname{se}\left(\sum E\right)$, is defined by the following:

$$
\operatorname{se}\left(\sum E\right)=\sqrt{\frac{\sum E \times\left(\sum N-\sum E\right)}{\sum N} .}
$$

If the leaf has error not larger than $\sum E+\operatorname{se}\left(\sum E\right)$ after $S$ has been replaced by the best leaf, the subtree is replaced with the leaf. This procedure makes the decision tree the simplest and the lowest error for given training sets.

\section{APPLICATION AND RESULTS}

Based upon past experiences on vibration of the rotating machines considered, we divided causes of vibration into 14 classes, and divided vibration phenomena into 20 attributes, which are summarized in Tables I and II. These classes and attributes are enough to represent vibration characteristics of

TABLE I Class of the decision tree

\begin{tabular}{rll}
\hline No. & \multicolumn{1}{c}{ Class (cause of vibration) } & \multicolumn{1}{c}{ Symbol } \\
\hline 1 & Mechanical unbalance & Unbalance \\
2 & Misalignment & Misalignment \\
3 & Partial rub & Partial rub \\
4 & Crack & Crack \\
5 & Mechanical looseness & Looseness \\
6 & Ball bearing damage & Ball bearing damage \\
7 & Foundation distortion & Foundation distortion \\
8 & Critical speed(1× resonance) & Critical speed \\
9 & Subharmonic resonance & Subharmonic resonance \\
10 & Oil whip/oil whirl & Oil whip/whirl \\
11 & Vane passing vibration & Vane passing vibration \\
12 & Clearance induced vibration & Clearance induced vib. \\
13 & Static eccentricity of air gap & Static air gap \\
& or stator damage & \\
14 & Dynamic eccentricity of air gap & Dynamic air gap \\
& or rotor damage & \\
\hline
\end{tabular}


TABLE II Attribute and attribute value of the decision tree

\begin{tabular}{|c|c|c|c|c|}
\hline No. & Attribute & Symbol & Attribute value & Symbol \\
\hline 1 & What is the predominant frequency? & Predominant frequency & $\begin{array}{l}1 \times \text { component } \\
2 \times \text { component } \\
1 \times \text { and } 2 \times \\
\text { harmonics of } 1 \times \\
\text { higher components } \\
\text { more than } 1 \times \\
\text { lower components } \\
\text { less than } 1 \times\end{array}$ & $\begin{array}{l}1 \times \\
2 \times \\
\text { like same } \\
\text { multiples } \\
\text { higher } \\
\text { lower }\end{array}$ \\
\hline 2 & Is there a natural frequency? & Natural frequency & $\begin{array}{l}\text { yes } \\
\text { no }\end{array}$ & $\begin{array}{l}\text { yes } \\
\text { no }\end{array}$ \\
\hline 3 & Is $0.4-0.48 \times$ component predominant? & $0.4-0.48 \times$ & $\begin{array}{l}\text { yes } \\
\text { no }\end{array}$ & $\begin{array}{l}\text { yes } \\
\text { no }\end{array}$ \\
\hline 4 & Is $0.5-1 \times$ component predominant? & $0.5-1 \times$ & $\begin{array}{l}\text { yes } \\
\text { no }\end{array}$ & $\begin{array}{l}\text { yes } \\
\text { no }\end{array}$ \\
\hline 5 & Is bearing damage frequency predominant? & $Z f_{\text {bearing }}$ & $\begin{array}{l}\text { yes } \\
\text { no }\end{array}$ & $\begin{array}{l}\text { yes } \\
\text { no }\end{array}$ \\
\hline 6 & Is vane passing frequency predominant? & $Z f_{\text {vane }}$ & $\begin{array}{l}\text { yes } \\
\text { no }\end{array}$ & $\begin{array}{l}\text { yes } \\
\text { no }\end{array}$ \\
\hline 7 & Is subharmonic predominant? & Subharmonic & $\begin{array}{l}\text { yes } \\
\text { no }\end{array}$ & $\begin{array}{l}\text { yes } \\
\text { no }\end{array}$ \\
\hline 8 & Is there harmonics of $1 / 2 \times$ component? & 1/2-multiple & $\begin{array}{l}\text { yes } \\
\text { no }\end{array}$ & $\begin{array}{l}\text { yes } \\
\text { no }\end{array}$ \\
\hline 9 & Is there intense noise at the high frequency area? & High frequency & $\begin{array}{l}\text { yes } \\
\text { no }\end{array}$ & $\begin{array}{l}\text { yes } \\
\text { no }\end{array}$ \\
\hline 10 & Is there line frequency? & $f_{0}$ & $\begin{array}{l}\text { yes } \\
\text { no }\end{array}$ & $\begin{array}{l}\text { yes } \\
\text { no }\end{array}$ \\
\hline 11 & Is there two times frequency as large as line frequency? & $2 f_{0}$ & $\begin{array}{l}\text { yes } \\
\text { no }\end{array}$ & $\begin{array}{l}\text { yes } \\
\text { no }\end{array}$ \\
\hline 12 & Is there a pulsation component, $2 s f_{0}$ & Pulse & $\begin{array}{l}\text { yes } \\
\text { no }\end{array}$ & $\begin{array}{l}\text { yes } \\
\text { no }\end{array}$ \\
\hline 13 & Do phase and amplitude of $1 \times$ component change? & $1 \times$-change & $\begin{array}{l}\text { yes } \\
\text { no }\end{array}$ & $\begin{array}{l}\text { yes } \\
\text { no }\end{array}$ \\
\hline 14 & Do phase and amplitude of $2 \times$ component change? & $2 \times$-change & $\begin{array}{l}\text { yes } \\
\text { no }\end{array}$ & $\begin{array}{l}\text { yes } \\
\text { no }\end{array}$ \\
\hline 15 & Does runout vector change? & Runout change & $\begin{array}{l}\text { yes } \\
\text { no }\end{array}$ & $\begin{array}{l}\text { yes } \\
\text { no }\end{array}$ \\
\hline 16 & Is axial amplitude larger than lateral amplitude? & Axial amplitude & $\begin{array}{l}\text { yes } \\
\text { no }\end{array}$ & $\begin{array}{l}\text { yes } \\
\text { no }\end{array}$ \\
\hline 17 & Is orbit shape leaning to one side or eight shape? & Orbit shape & $\begin{array}{l}\text { yes } \\
\text { no }\end{array}$ & $\begin{array}{l}\text { yes } \\
\text { no }\end{array}$ \\
\hline 18 & What is direction of orbit? & Orbit direction & $\begin{array}{l}\text { forward direction } \\
\text { backward direction }\end{array}$ & $\begin{array}{l}\text { forward } \\
\text { backward }\end{array}$ \\
\hline 19 & How is amplitude change during shut-down? & Shut-down & $\begin{array}{l}\text { almost constant } \\
\text { decrease at the same ratio } \\
\text { temporary pause } \\
\text { drop out suddenly }\end{array}$ & $\begin{array}{l}\text { stays same } \\
\text { decrease } \\
\text { temporary pause } \\
\text { rapidly drop }\end{array}$ \\
\hline 20 & What is predominant location of vibration? & Location & $\begin{array}{l}\text { shaft } \\
\text { bearing } \\
\text { pipe system } \\
\text { casing } \\
\text { coupling }\end{array}$ & $\begin{array}{l}\text { shaft } \\
\text { bearing } \\
\text { piping } \\
\text { casing } \\
\text { coupling }\end{array}$ \\
\hline
\end{tabular}


most rotating machines. The classes taken can be divided into three groups, depending upon sources of the vibration. The first group includes mechanical unbalance, misalignment, partial rub, crack, mechanical looseness, ball bearing damage, foundation distortion, and critical speed. These are mechanical faults. The second group is related with fluid flow in the machines, and includes subharmonic resonance, oil whirl/whip, vane passing vibration, and clearance induced vibration. The third group is related with electrical faults, and includes static eccentricity of air gap or stator damage and dynamic eccentricity of the air gap or rotor damage.

The attributes taken are frequency, amplitude, phase, trend, and location of vibration. Since vibration spectra usually contain such information for diagnostics, the frequency is divided into several components as shown in the tables. The classes and attributes are represented with corresponding symbols for implementation in the expert system.

We utilized the cause-result matrix (Sohre, 1980) in order to construct training set for decision tree. Sohre's cause-result matrix has been utilized in most automatic vibration diagnosis system. But this decision tree using Sohre's cause-result matrix was short of reliability. So, both attribute and class were defined again, and a new result-cause matrix improving its reliability was developed to induce vibration diagnosis decision tree. Table III shows a part of new result-cause matrix. The values in the table implies probability of frequency components for the vibration causes. Figure 2 shows the decision tree inducting throughout this training set.

The decision tree was applied to diagnostics for various rotating machines. Sample cases were taken from published work. Results of the diagnostics are summarized in Table IV. The table compares diagnostic result from using the present method with those obtained from the conventional causeresult matrix proposed by Sohre (1980). As shown in the table, the present method is found to predict causes of vibration more reasonably than the conventional method.
TABLE III Result-cause matrix of classes to attributes

\begin{tabular}{|c|c|c|c|c|c|c|}
\hline \multirow[b]{2}{*}{ Vibration cause } & \multicolumn{6}{|c|}{ Predominant frequency } \\
\hline & $1 \times$ & $2 \times$ & $\begin{array}{l}\text { Almost } \\
\text { same }\end{array}$ & Multiples & Higher & Lower \\
\hline Unbalance & $30 \%$ & & $30 \%$ & & & \\
\hline Misalignment & & $50 \%$ & $70 \%$ & $30 \%$ & & \\
\hline Partial rub & $13 \%$ & $8 \%$ & & $13 \%$ & $10 \%$ & $20 \%$ \\
\hline Crack & & $30 \%$ & & $13 \%$ & & \\
\hline Looseness & & & & $38 \%$ & & \\
\hline $\begin{array}{l}\text { Ball bearing } \\
\text { damage }\end{array}$ & $13 \%$ & & & & $30 \%$ & \\
\hline $\begin{array}{l}\text { Foundation } \\
\text { distortion }\end{array}$ & & $12 \%$ & & & & $15 \%$ \\
\hline Critical speed & $13 \%$ & & & & & \\
\hline $\begin{array}{l}\text { Subharmonic } \\
\text { resonance }\end{array}$ & & & & & & $20 \%$ \\
\hline Oil whip/whirl & $5 \%$ & & & $6 \%$ & & $25 \%$ \\
\hline $\begin{array}{l}\text { Vane passing } \\
\text { vibration }\end{array}$ & $13 \%$ & & & & $30 \%$ & \\
\hline $\begin{array}{l}\text { Clearance induced } \\
\text { vibration }\end{array}$ & & & & & & $20 \%$ \\
\hline Static air gap & & & & & $30 \%$ & \\
\hline Dynamic air gap & $13 \%$ & & & & & \\
\hline
\end{tabular}

For an example, we take the case \#2 in the table. This case represents an excessive vibration of a centrifugal fan with 24 vanes running at $3360 \mathrm{rpm}$. The vibration spectrum is shown in Fig. 3. From the spectrum, we see that the vibration is higher at $1344 \mathrm{~Hz}$ than at the running speed $(56 \mathrm{~Hz})$. The vane passing frequency is the product of the running speed times the number of vanes, which is $1344 \mathrm{~Hz}(56 \mathrm{~Hz} \times 24=1344 \mathrm{~Hz})$. For this case, the decision tree first searches for condition of the predominant frequency, resulting in "higher". Then, the next step decides if the high frequency is originated from the ball bearing damage or the vane passing vibration. In this case, information on ball bearings are not available. Thus, the final diagnostics results in $90 \%$ probability of the vane passing vibration instead of $100 \%$ probability.

For another example, we take the case \#4 in the table. This case is an excessive vibration of a centrifugal pump due to misalignment. The pump runs at $3600 \mathrm{rpm}$. In Fig. 4, vibration amplitudes 


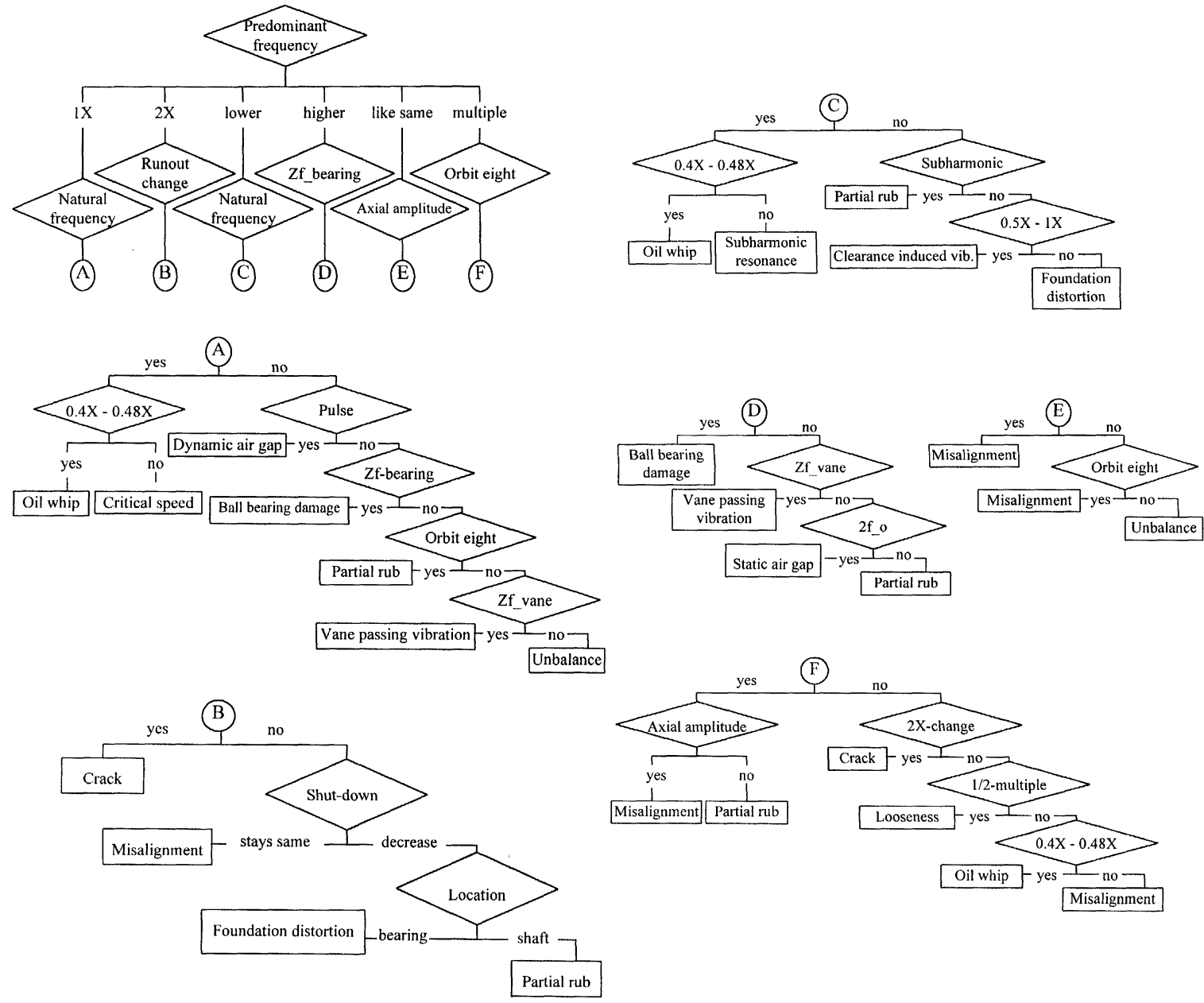

FIGURE 2 Decision tree for vibration diagnostics.

are summarized for each location of measurement. The vibration amplitude is the highest at the inner bearing, with $40.665 \mathrm{~mm} / \mathrm{s}$. The highest frequency component is $120 \mathrm{~Hz}$, i.e., $2 \times$ revolution vibration, as shown in Fig. 4. In diagnosing the vibration, the present method first asks the frequency component and then $2 \times$ is selected. In the next step, the run-out vector is checked. For this case, since data on the run-out vector is not known, the more probable branch is selected, based on probabilistic branching by the branching algorithm of the present method. In the next step, amplitude change during shut down is checked. Since data is not known, the same principle is applied, as in the previous step. In the final step, the location of the most severe vibration is checked. The diagnostic result shows that misalignment is the primary source of vibration with probability of $47 \%$. In this sample case, since known data are very restricted, the probability is not so high although the primary source of vibration is correctly diagnosed. Thus, when one diagnoses the vibration of the rotating machines, one has to acquire as much data as possible, including not only steady state and transient vibration data but also data on operation of the machines. 
TABLE IV Diagnostics result of rotating machinery

\begin{tabular}{|c|c|c|c|c|c|c|}
\hline \multirow[t]{2}{*}{ Machines } & & \multirow[t]{2}{*}{ Vibration cause } & \multicolumn{4}{|c|}{ Diagnosis result } \\
\hline & & & Result-cause matrix & & Cause-result matrix & \\
\hline 1 & Induction motor, Wowk (1991) & Looseness & $\begin{array}{l}\text { Looseness } \\
\text { the others }\end{array}$ & $\begin{array}{l}50 \% \\
50 \%\end{array}$ & $\begin{array}{l}\text { Unbalance } \\
\text { the others }\end{array}$ & $\begin{array}{l}36 \% \\
64 \%\end{array}$ \\
\hline 2 & Centrifugal fan, Wowk (1991) & Vane passing vibration & $\begin{array}{l}\text { Vane passing vibration } \\
\text { Ball bearing damage }\end{array}$ & $\begin{array}{l}90 \% \\
10 \%\end{array}$ & $\begin{array}{l}\text { Bearing damage } \\
\text { Seal rub }\end{array}$ & $\begin{array}{l}67 \% \\
33 \%\end{array}$ \\
\hline 3 & Centrifugal pump, Mitchell (1993) & Vane passing vibration & $\begin{array}{l}\text { Vane passing vibration } \\
\text { Ball bearing damage }\end{array}$ & $\begin{array}{l}90 \% \\
10 \%\end{array}$ & $\begin{array}{l}\text { Vane passing vibration } \\
\text { the others }\end{array}$ & $\begin{array}{l}75 \% \\
25 \%\end{array}$ \\
\hline 4 & Centrifugal pump, Miguel (1996) & Misalignment & $\begin{array}{l}\text { Misalignment } \\
\text { Foundation distortion }\end{array}$ & $\begin{array}{l}47 \% \\
53 \%\end{array}$ & $\begin{array}{l}\text { Misalignment } \\
\text { the others }\end{array}$ & $\begin{array}{l}45 \% \\
55 \%\end{array}$ \\
\hline 5 & Draft fan, Wowk (1991) & Misalignment & $\begin{array}{l}\text { Misalignment } \\
\text { the others }\end{array}$ & $\begin{array}{l}54 \% \\
46 \%\end{array}$ & $\begin{array}{l}\text { Vane passing vibration } \\
\text { Seal rub }\end{array}$ & $\begin{array}{l}90 \% \\
10 \%\end{array}$ \\
\hline 6 & Fan, Wowk (1991) & Unbalance & $\begin{array}{l}\text { Unbalance } \\
\text { the others }\end{array}$ & $\begin{array}{l}29 \% \\
71 \%\end{array}$ & $\begin{array}{l}\text { Unbalance } \\
\text { the others }\end{array}$ & $\begin{array}{l}36 \% \\
64 \%\end{array}$ \\
\hline 7 & Steam turbine, Mariano (1993) & Misalignment & Misalignment & $100 \%$ & Misalignment & $100 \%$ \\
\hline 8 & Turbo-blower, Maegawa (1990) & Oil whip & $\begin{array}{l}\text { Oil whip/whirl } \\
\text { the others }\end{array}$ & $\begin{array}{l}72 \% \\
28 \%\end{array}$ & $\begin{array}{l}\text { Oil whip } \\
\text { the others }\end{array}$ & $\begin{array}{l}59 \% \\
41 \%\end{array}$ \\
\hline 9 & Air compressor, Maki (1993) & Oil whip & $\begin{array}{l}\text { Oil whip/whirl } \\
\text { the others }\end{array}$ & $\begin{array}{l}53 \% \\
47 \%\end{array}$ & $\begin{array}{l}\text { Oil whip } \\
\text { the others }\end{array}$ & $\begin{array}{l}59 \% \\
41 \%\end{array}$ \\
\hline 10 & Centrifugal pump, Maki (1993) & Misalignment & $\begin{array}{l}\text { Misalignment } \\
\text { the others }\end{array}$ & $\begin{array}{l}51 \% \\
49 \%\end{array}$ & $\begin{array}{l}\text { Foundation distortion } \\
\text { Misalignment }\end{array}$ & $\begin{array}{l}80 \% \\
20 \%\end{array}$ \\
\hline
\end{tabular}

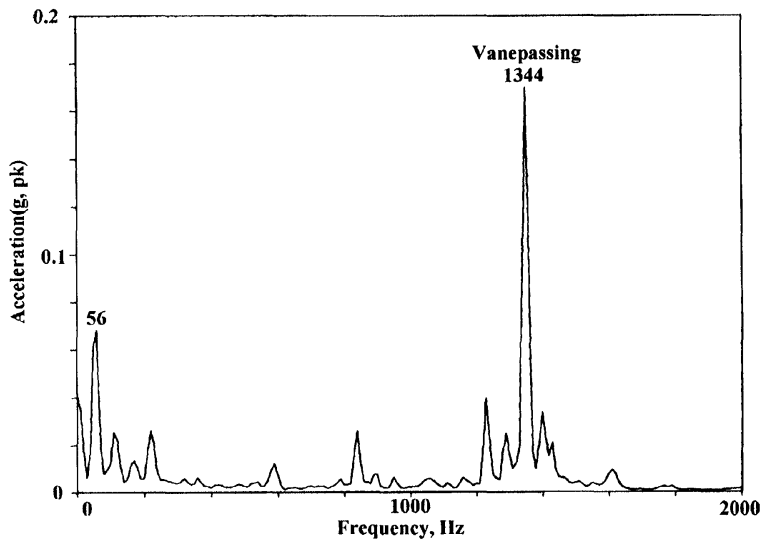

FIGURE 3 Vibration spectrum of centrifugal fan (Wowk, 1991).

\section{CONCLUSION}

A method of vibration diagnostics for rotating machines has been developed, using a decision tree with a result-cause matrix. The method was applied to a variety of rotating machines. It is found that the present method diagnoses vibration causes of the rotating machines relatively well. (a)

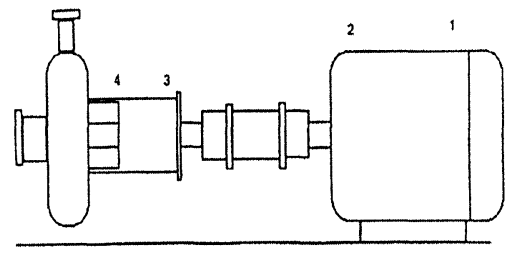

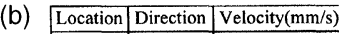

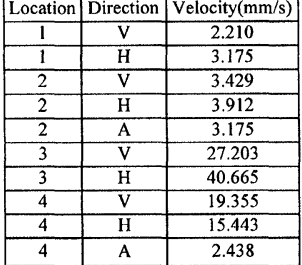

(c)

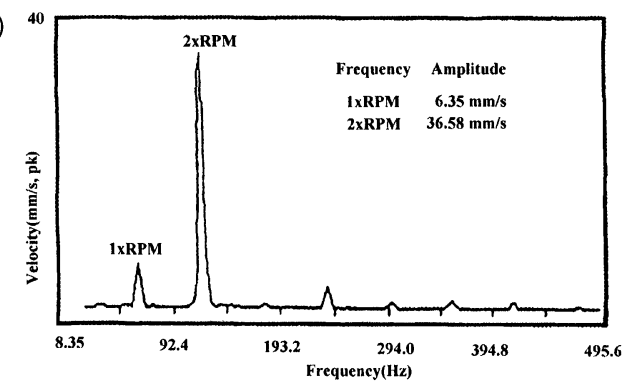

FIGURE 4 Vibration spectrum of centrifugal pump (Wowk, 1991). (a) Measuring points; (b) Overall vibration level; (c) Vibration spectrun at the location $3 \mathrm{H}$. 


\section{NOMENCLATURE}

\begin{tabular}{|c|c|}
\hline$C_{j}$ & $j$-th class \\
\hline$F$ & $\begin{array}{l}\text { ratio of a cause with known } \\
\text { attribute values to total cases }\end{array}$ \\
\hline $\operatorname{freq}\left(C_{j}, T\right)$ & $\begin{array}{l}\text { number of classes belonging } \\
\text { to } C_{j} \text { in } T\end{array}$ \\
\hline $\operatorname{gain}(X)$ & mutual information \\
\hline $\operatorname{GR}(X)$ & $\begin{array}{l}\text { ratio of the mutual information } \\
\text { to the split information }\end{array}$ \\
\hline $\operatorname{info}_{X}(T)$ & expeted information \\
\hline$k$ & number of classes \\
\hline$n$ & number of outcomes of test $X$ \\
\hline $\begin{array}{l}O_{i} \\
\text { split info(X) }\end{array}$ & $\begin{array}{l}\text { possible outcome of } T_{i} \\
\text { split information }\end{array}$ \\
\hline$T$ & training set \\
\hline$T_{i}$ & subset of $T$ \\
\hline$|T|$ & number of cases \\
\hline$T_{\text {known }}$ & $\begin{array}{l}\text { set of cases with known } \\
\text { attribute values }\end{array}$ \\
\hline$X$ & $\begin{array}{l}\text { any decision rule with possible } \\
\text { outcomes } O_{1}, O_{2}, \ldots, O_{n}\end{array}$ \\
\hline
\end{tabular}

\section{References}

Maegawa, K. (1990) Plant Diagnosis Technique, Japanese Plant Maintenance Association, Tokyo, p. 107.

Maki, S.L. (1993) Practice of Machine Diagnosis Technique by Vibration Method, Japanese Plant Maintenance Association, Tokyo, p. 268, 288.

Mariano, S.C. (1993) Misalignment and balancing problems at a refinery, $O R B I T$, pp. $20-22$.

Miguel de Priego, J.C. (1996) Vibration analysis of a centrifugal pump, Vibration, 12(3), 14-15.

Mitchell, J.S. (1993) Introduction to Machinery Analysis and Monitoring, Pennwell Books, Oklahoma, p. 203.

Mui, J.K. and Fu, K.S. (1980) Automated classification of nucleated blood cells using binary tree classifier, IEEE Trans. PAMI, 2-5, 429-443.

Quinlan, J.R. (1986) Induction of decision tree, Machine Learning, 1, 81-106

Quinlan, J.R. (1987) Simplifying decision trees, International Journal of Man-Machine Studies, 27, 221-234.

Quinlan, J.R. (1992) C4.5: Programs for Machine Learning, Morgan Kaufmann Publishers, California, 17-44.

Safavian, S.R. and Landgrebe, D. (1991) A survey of decision tree classifier methodology, IEEE Transactions on Systems, Man, and Cybernetics, 21(3), 660-674.

Sohre, J.S. (1980) Turbomachinery Problems and Their Correction, Sawyer's Turbomachinery Maintenance Handbook, Vol. 2, Gas Turbine Publications, Inc., Connecticut, Ch. 7.

Wowk, V. (1991) Machinery Vibration, Measurement and Analysis, McGraw-Hill, New York. Ch. 5. 


\section{ait \\ ENERGY MATERIALS}

M A N E Y publishing

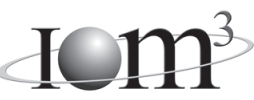

\section{Materials Science \& Engineering for Energy Systems}

Maney Publishing on behalf of the Institute of Materials, Minerals and Mining

The Institute of Materials, Minerals \& Mining

Economic and environmental factors are creating ever greater pressures for the efficient generation, transmission and use of energy. Materials developments are crucial to progress in all these areas: to innovation in design; to extending lifetime and maintenance intervals; and to successful operation in more demanding environments. Drawing together the broad community with interests in these areas, Energy Materials addresses materials needs in future energy generation, transmission, utilisation, conservation and storage. The journal covers thermal generation and gas turbines; renewable power (wind, wave, tidal, hydro, solar and geothermal); fuel cells (low and high temperature); materials issues relevant to biomass and biotechnology; nuclear power generation (fission and fusion); hydrogen generation and storage in the context of the 'hydrogen economy'; and the transmission and storage of the energy produced.

As well as publishing high-quality peer-reviewed research, Energy Materials promotes discussion of issues common to all sectors, through commissioned reviews and commentaries. The journal includes coverage of energy economics and policy, and broader social issues, since the political and legislative context influence research and investment decisions.

\section{CALL FOR PAPERS}

Contributions to the journal should be submitted online at http://ema.edmgr.com

To view the Notes for Contributors please visit: www.maney.co.uk/journals/notes/ema

Upon publication in 2006, this journal will be available via the Ingenta Connect journals service. To view free sample content online visit: www.ingentaconnect.com/content/maney

For further information please contact:

Maney Publishing UK

Tel: +44 (0)113 2497481 Fax: +44 (0)1132486983 Email: subscriptions@maney.co.uk

or

Maney Publishing North America

Tel (toll free): 8662975154 Fax: 6173546875 Email: maney@maneyusa.com

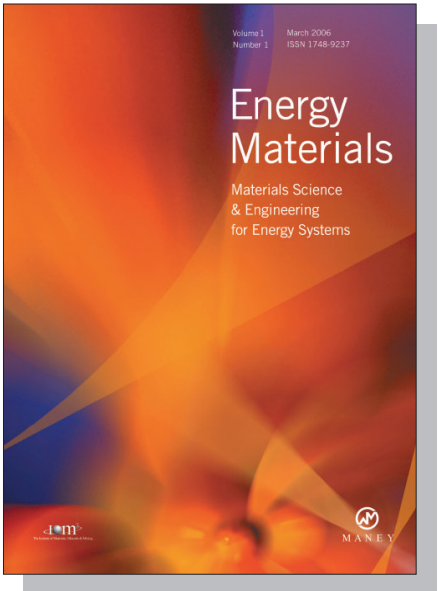

EDITORS

Dr Fujio Abe

NIMS, Japan

Dr John Hald, IPL-MPT, Technical University of Denmark, Denmark

Dr R Viswanathan, EPRI, USA

\section{SUBSCRIPTION INFORMATION}

Volume 1 (2006), 4 issues per year

Print ISSN: 1748-9237 Online ISSN: 1748-9245

Individual rate: $£ 76.00 / U S \$ 141.00$

Institutional rate: $£ 235.00 /$ US $\$ 435.00$

Online-only institutional rate: $£ 199.00 / U S \$ 367.00$

For special $\mathrm{IOM}^{3}$ member rates please email

subscriptions@maney.co.uk

\section{For further information or to subscribe online please visit www.maney.co.uk}



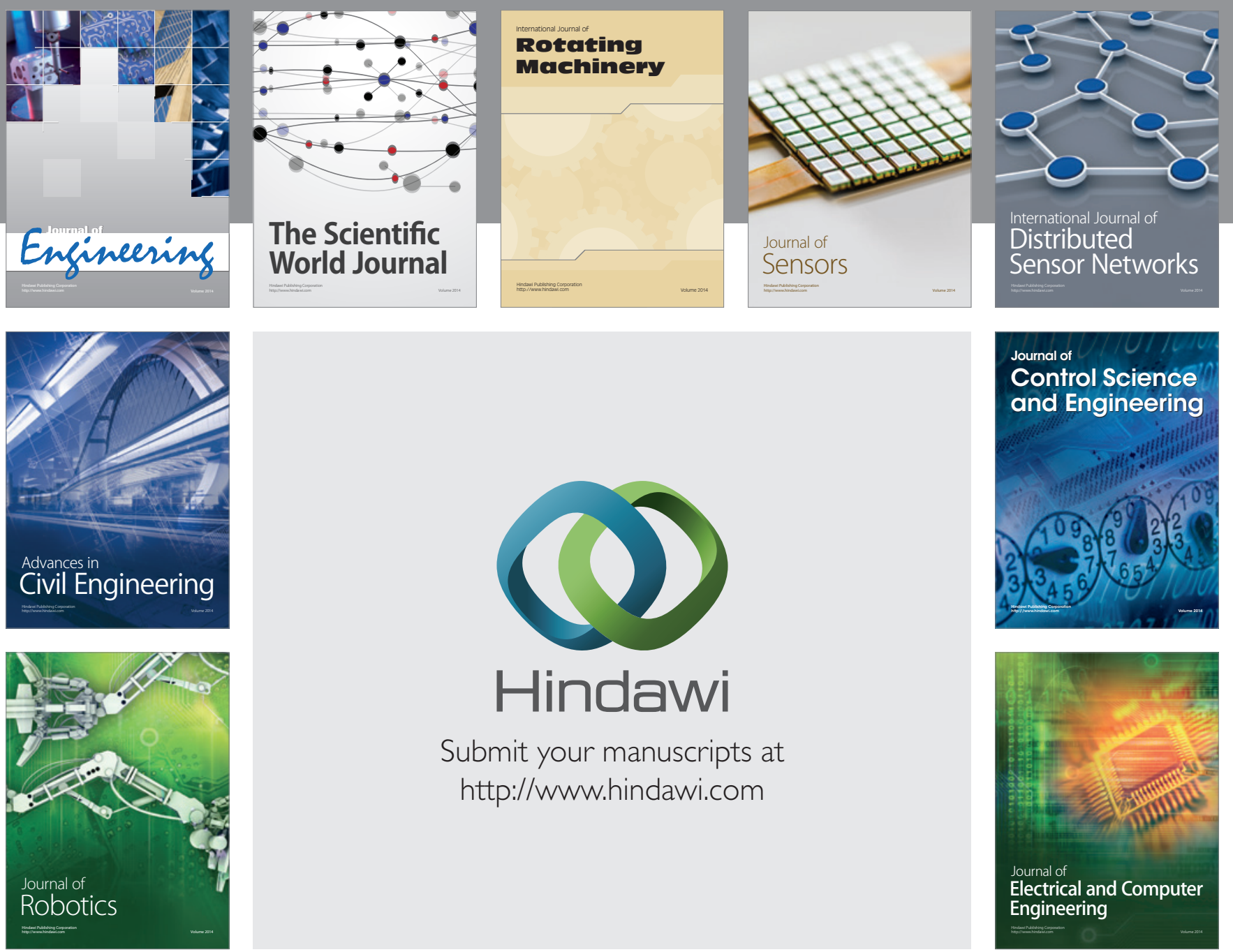

Submit your manuscripts at

http://www.hindawi.com
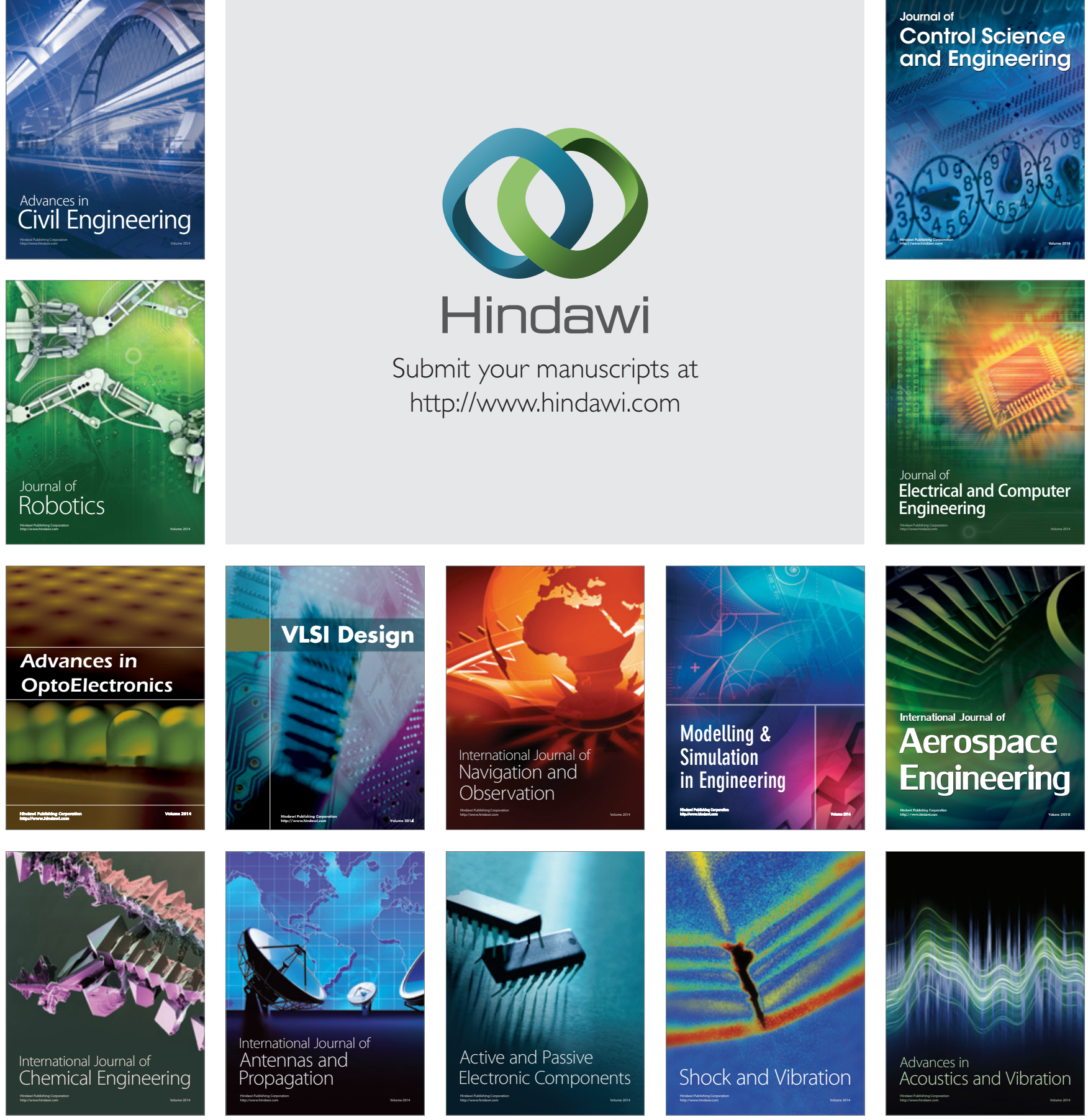